\title{
Risk factors and laboratory markers used to predict leakage in esophagojejunal anastomotic leakage after total gastrectomy
}

\author{
Durmuş Ali Çetin ${ }^{1}$, Ebubekir Gündeş ${ }^{2}$, Hüseyin Çiyiltepe ${ }^{3}$, Ulaş Aday ${ }^{4}$, Orhan Uzun ${ }^{5}$, Kamuran Cumhur Değer ${ }^{5}$, Mustafa Duman ${ }^{5}$ \\ 'Clinic of Gastroenterological Surgery, Sanliurfa Training and Research Hospital, Sanliurfa, Turkey \\ ${ }^{2}$ Clinic of Gastroenterological Surgery, Diyarbakir Gazi Yaşargil Training and Research Hospital, Diyarbakir, Turkey \\ ${ }^{3}$ Clinic of Gastroenterological Surgery, Fatih Sultan Mehmet Training and Research Hospital, Istanbul, Turkey \\ ${ }^{4}$ Clinic of Gastroenterological Surgery, Elazig Training and Research Hospital, Elazig, Turkey \\ ${ }^{5}$ Clinic of Gastroenterological Surgery, Kartal Kosuyolu High Specialization Training and Research Hospital, Istanbul, Turkey
}

\section{ABSTRACT}

Objective: Esophagojejunal anastomotic leakages, which occur in the reconstruction procedures performed after total or proximal gastrectomy, still account for one of the most significant causes of morbidity and mortality in spite of the developments seen in perioperative management and surgical techniques in gastric cancer surgery. The aim of the present study was to ascertain the risk factors for Esophagojejunal anastomotic leakages.

Material and Methods: A total of 80 patients with gastric cancer, who had total gastrectomy +D2 lymph node dissection and Esophagojejunal anastomotic between January 2013 and December 2016, were retrospectively evaluated. Patients who did not have anastomotic leakages during their clinical follow-ups were allocated to Group 1, whereas those who had anastomotic leakages were allocated to Group 2.

Results: A total of $58(72.5 \%)$ out of 80 patients were males, whereas 22 (27.5\%) were females. Mean age of the patients was $61.2 \pm 11.2$ years. There were no demographic differences between the groups. Postoperative recurrent fever $(p=0.001)$, C-reactive protein values on postoperative days 3 and 5 ( $p=$ $0.01)$, and neutrophil-to-lymphocyte ratio on postoperative day $5(p=0.022)$ were found to be statistically significant with regard to Esophagojejunal anastomotic leakages and other postoperative complications. The duration of operation $(p=0.032)$ and combined organ resection $(p=0.008)$ were ascertained as risk factors for Esophagojejunal anastomotic leakages.

Conclusion: Surgeons should be careful about Esophagojejunal anastomotic leakages which are significant postoperative complications seen especially in cases where the duration of operation is prolonged, and additional organ resections are performed. Recurrent fever, high C-reactive protein levels, and neutrophil-to-lymphocyte ratio may serve as warnings for complications in postoperative follow-ups.

Keywords: Anastomosis leakage, gastrectomy, risk factors

Cite this article as: Çetin DA, Gündeş E, Çiyiltepe $H$, Aday U, Uzun O, Değer KC, et al. A. Risk factors and laboratory markers used to predict leakage in esophagojejunal anastomotic leakage after total gastrectomy. Turk J Surg 2019; 35 (1): 6-12

Corresponding Author

Durmuş Ali Çetin

E-mail: drdurmusalicetin@gmail.com

Received: 05.05.2018

Accepted: 19.02 .2018

Available Online Date: 20.11.2018

o Copyright 2019 by Turkish Surgical Society Available online at www.turkjsurg.com

DOI: $10.5578 /$ turkjsurg.4117

\section{INTRODUCTION}

Surgical treatment focuses on the balance between risk and reward. The most important components of postoperative care include predicting the possible secondary problems regarding the procedure, preventing these problems, noticing them early on, and rightly performing the appropriate intervention for treatment on time. In spite of all these, complications may not always be prevented. As long as surgical procedures are performed, surgeons will have to deal with complications as well. Therefore, it is inevitable that novel findings and information on this issue will accumulate, and novel perspectives will develop in modern practices. Anastomotic leakages still prove to be a major problem for surgeons although many studies have been conducted on the issue.

Anastomotic leakage is one of the most significant complications of postoperative gastric surgery and has a high rate of morbidity and mortality $(1,2)$. Securing a safe and sound esophagojejunal anastomosis (EJA) after total gastrectomy is one of the most important problems of gastric surgeons. The incidence of EJA leakages has decreased with experiences achieved during the learning curve and the common use of mechanical stapler tools (3). It is, however, still challenging to completely prevent anastomotic leakage, and the incidence of EJA leakages has been reported to be between $1 \%$ and $11 \%(3-11)$. 
The aim of the present study was to ascertain the risk factors for EJA leakage in patients who had total gastrectomy +D2 lymph node dissection due to gastric cancer and to unveil the presence of biochemical markers that could be utilized to predict them before they clinically developed.

\section{MATERIAL and METHODS}

\section{Patients}

A total of 80 patients with gastric cancer, who had total gastrectomy +D2 lymph node dissection and EJA between January 2013 and December 2016 at Kartal Koşuyolu Higher Specialty Training and Research Hospital's Gastroenterology Surgery Clinic, were retrospectively evaluated. The study was approved by the ethics committee of Kartal Koşuyolu Higher Specialty Training and Research Hospital (no. 2017.3/2-36). Informed consent was obtained from each patient for surgical intervention prior to surgery.

Patients who had immunosuppressive treatment; who had inflammatory diseases; who received neoadjuvant treatment; who had D1 lymph node dissection; who had surgical procedures due to gastrointestinal stromal tumor, gastric lymphoma, and other gastric tumors; who had palliative surgeries; and who had missing data in their files were excluded from the study.

All patients had oral intravenous contrasted thoracoabdominal computed tomography (CT) and positron emission tomography in suspected cases prior to surgical procedures. All patients for whom a surgical procedure was planned were started on preoperative enteral feeding. Feeding was reinitiated on postoperative day 1 through intraoperative nasojejunal catheters. Curative resection was performed for those patients without distant organ metastasis or major vascular invasion. Patients who did not have anastomotic leakages during their clinical follow-ups formed Group 1, whereas those who had anastomotic leakages formed Group 2.

\section{Surgical Technique}

All patients received total gastrectomy +D2 lymph node dissection and omentectomy. Intestinal reconstruction was performed in the form of Roux-en-Y esophagojejunostomy.

EJA was performed by a circular stapler ILS (Ethicon Endo-Surgery, Inc., Cincinnati, OH, USA) in the form of end-to-side in all cases. The size of the stapler was determined based on the diameter of the esophagus of the patient and the judgment of the surgical team. A $25 \mathrm{~mm}$ stapler was generally used for patients with normal sized esophagus. Wider staplers (28-29 mm) were used for patients with a wider esophagus. The circle, which was removed after the anastomosis was completed, was immediately controlled in all cases. Additional organ resection was performed for patients with intraoperative organ invasion and/or iatrogenic additional organ injury (spleen, pancreas, colon, and liver).

\section{Diagnosis of EJA Leakage}

Diagnosis of anastomotic leakage was predicted upon clinical and radiological results. Radiological leakage was defined as extravasation outside the lumen seen under endoscopy during the drinking of water-soluble contrast agent (WSCA), observation of the drunk contrast agent outside the lumen in $C T$, determination of abscess with air collection at anastomotic neighboring, detection of defects at the anastomotic line, and observation of defects in the anastomosis as revealed by endoscopic assessment. Clinical leakage was defined as the leak of intestinal and/or purulent content from the surgical incision or drains, fever, deteriorating abdominal pain, increase in C-reactive protein (CRP) and leukocyte levels, and determination of leakage during relaparotomy for abdominal sepsis. Radiological imaging performed after WSCA was carried out routinely for all patients.

\section{Data}

Data on age, sex, body mass index (BMI), left ventricular ejection fraction, respiratory function parameters (forced expiratory volume (FEV) and forced vital capacity (FVC)), preoperative albumin and peripheral blood results, durations of surgical procedures, presence or absence of additional organ resection, need for intraoperative blood transfusion, duration of hospitalization, postoperative clinical characteristics, and CRP and all blood values were recorded. Recurrent fever was defined as fever that lasted for at least 3 days and was over $38^{\circ} \mathrm{C}$.

Echocardiography was performed by a $2.5 \mathrm{MHz}$ probe in the left lateral decubitus position. Ejection fraction was calculated according to the modified Simpson method. The height $(\mathrm{cm})$ and body weight $(\mathrm{kg}$ ) of all patients were used to calculate their BMI for spirometric calculations. Each patient was asked to perform forced expiration after deep inspiration in a sitting position. Calculations were conducted by a dry spirometer tool according to the recommendations of the American Thoracic Society (ATS) (12). The best calculation out of three conducted for each case was recorded. FVC and FEV in one second $\left(\mathrm{FEV}_{1}\right)$ were recorded within the scope of spirometric measurements. Expected values were assessed according to the ATS criteria (12).

Peripheral blood samples were extracted to determine hematocrit, leukocyte, neutrophil, lymphocyte, and platelet counts. The neutrophil-to-lymphocyte ratio (NLR) was calculated by dividing the number of neutrophils by the number of lymphocytes, whereas the platelet-to-lymphocyte ratio was calculated by dividing the number of platelets by the number of lymphocytes.

The duration of hospitalization was accepted to be the period from the day of surgical procedure to discharge, whereas inhospital mortality was accepted to be the case of mortality seen during hospitalization or during the first 30 days following surgery. Postoperative complications were ranked according to the Clavien-Dindo Classification of surgical complications (13). Patients 
without anastomotic leakage but with postoperative complications were set as other complications.

Postoperative other complications included surgical site infection, pneumonia, postoperative atelectasis, cheilosis leakage, evisceration, acute renal failure, and intra-abdominal hemorrhage.

The American Joint Committee on Cancer classification system's seventh TNM staging was used for the histopathological staging of all cases (14).

\section{Statistical Analysis}

Statistical Package for the Social Sciences software (SPSS Inc., Chicago, IL, USA) was used in all biostatistical analyses. Data from the study were expressed in mean figures, standard deviation values, and percentages as necessary. Kolmogorov-Smirnov test was used to check the distribution of the collected data. ANOVA test was utilized for the multiple group comparisons of normally distributed data, whereas Student's t-test was used for binary group comparisons.

Multiple group comparisons of non-parametric data were conducted through Kruskal-Wallis analysis, whereas binary group comparisons were performed by Mann-Whitney $U$ test. The comparison of categorical groups was conducted by Chi-square test. Multivariate analysis was conducted for intraoperative results that were found to be statistically significant according to univariate analysis. The results were set at 95\% confidence interval (Cl). A $p<0.05$ was considered as statistically significant.

\section{RESULTS}

Of the 80 patients, 58 (72.5\%) were males, whereas 22 (27.5\%) were females. Mean age of the patients was $61.2 \pm 11.2$ years. There were 67 (83.8\%) patients in Group 1 with no EJA leakage findings during their clinical follow-ups, whereas there were 13 (16.2\%) patients in Group 2 with EJA leakage. Both groups had similar demographic $s$ and preoperative laboratory results (Table $1)$.

When intraoperative findings and pathological results were investigated, it was ascertained that additional organ resection $(p=0.002)$ and prolonged intraoperative time $(p=0.007)$ significantly increased the rate of EJA leakage. It was seen that all patients with EJA leakage had T3 (69.2\%) and T4 (30.8\%) tumors, but no statistically significant difference was found. The total number of excised and the number of metastatic lymph nodes, the $\mathrm{N}$ stage of tumor, and intraoperative blood transfusion were not found to be statistically significant with regard to EJA leakage. Table 2 shows intraoperative and pathological data of patients. The results of the multivariate analysis revealed that additional organ resection ( $p=0.008$, odds ratio (OR) 6.329, 95\% Cl 0.040$0.623)$ and the duration of operation $(p=0.032$, OR 10.416, 95\% $\mathrm{Cl}$ 0.011-0.820) were independent risk factors for EJA leakage (Table 3).
Further, all patients were divided into three subgroups according to those with EJA leakage, those with postoperative complications other than anastomotic leakage, and those without. When data on these patients' postoperative fever and laboratory results up to postoperative day 5 were investigated, it was seen that 7 out of 13 patients with EJA leakage had fever, and 6 had recurrent fever. Of the 21 patients, 12 had postoperative complications, but no anastomotic leakage and fever, and 4 had recurrent fever. The rate of EJA leakage and postoperative complications in patients with postoperative recurrent fever was found to be significantly higher $(p=0.01)$. When CRP values were assessed, it was observed that CRP values on postoperative days 3 and 5 were higher in patients with postoperative complications including EJA leakage than in those with no complications, and the difference was statistically significant $(p=0.01)$. There was, however, no statistically significant difference with regard to CRP values between patients with EJA and those with postoperative complications other than anastomotic leakage. Moreover, when the patients were evaluated according to their NLR, it was seen that NLR on postoperative day 5 was significantly higher in EJA leakage and other postoperative complications group ( $p=$ 0.022). There was no statistically significant difference regarding NLR on postoperative days 1 and 3. Table 4 shows patients' postoperative laboratory results and fever values.

The average duration from operation to the day on which the leakage was identified among 13 patients with EJA leakage was 6.3 (3-8) days. The average duration of hospitalization for patients with EJA leakage was $35 \pm 30$ days, whereas it was $13 \pm 7$ days for patients without EJA leakage. When the cases of patients with EJA leakage were ranked according to the modified Clavien-Dindo Classification of surgical complications, it was seen that 4 patients had grade 2, 4 patients had grade 3a, 2 patients had grade $3 b, 2$ patients had $4 a$, and 1 patient had grade 5 complications. Covered self-expandable metal stents were endoscopically placed in 2 out of 13 patients with EJA leakage. One (7.7\%) patient with stent died due to multiorgan failure. Two patients needed reoperation. Five patients received radiological percutaneous drainage under local anesthesia due to intra-abdominal abscess. Four patients were treated conservatively.

\section{DISCUSSION}

It has been stated that the developments in surgical techniques and perioperative management decreases the rate of EJA leakage after total or proximal gastrectomy. The incidence of EJA leakage has been reported to be between 1.0\% and 11.5\% (3-11). The rate of leakage reported by high-volume Japanese centers, however, wis 1.0\%-2.1\% (2,3,5,8). The Japanese National Clinical Database on digestive surgery reported that the incidence of anastomotic leakage after total gastrectomy in 2014 was 4.4\% (881/20011) (15). Surgeons should be careful when forming an anastomosis in order to prevent this dangerous complication. 


\begin{tabular}{|c|c|c|c|c|}
\hline Variable & & $\begin{array}{l}\text { Anastomosis leakage (-) } \\
\qquad n=67\end{array}$ & $\begin{array}{l}\text { Anastomosis leakage (+) } \\
\qquad n=13\end{array}$ & $\mathrm{p}$ \\
\hline \multirow[t]{2}{*}{ Gender ${ }^{\#}$} & Male & $48(60)$ & $10(12.5)$ & 0.696 \\
\hline & Female & $19(23.8)$ & $3(3.8)$ & \\
\hline Age $^{*}$ (year) & & $61 \pm 12$ & $65 \pm 9$ & 0.161 \\
\hline \multirow[t]{3}{*}{$\mathrm{ASA}^{\#}$} & 1 & $10(14.9)$ & $1(7.7)$ & 0.612 \\
\hline & 2 & $27(40.3)$ & $7(53.8)$ & \\
\hline & 3 & $30(44.8)$ & $5(38.5)$ & \\
\hline \multirow[t]{10}{*}{ Comorbidities $^{\#}$} & HTYes & $17(25.4)$ & $3(23.1)$ & 0.861 \\
\hline & No & $50(74.6)$ & $10(76.9)$ & \\
\hline & DMYes & $15(22.4)$ & $2(15.4)$ & 0.572 \\
\hline & No & $52(77.6)$ & $11(84.6)$ & \\
\hline & COPD Yes & $13(19.4)$ & $1(7.7)$ & \\
\hline & No & $54(80.6)$ & $12(92.3)$ & \\
\hline & CRF Yes & $1(1.5)$ & 0 & \\
\hline & No & $66(98.5)$ & $13(100)$ & \\
\hline & CAD Yes & $7(10.4)$ & $3(23.1)$ & \\
\hline & No & 60 (89.6) & $10(76.9)$ & \\
\hline \multirow[t]{2}{*}{ History of smoking } & Yes & $21(31.3)$ & $4(30.8)$ & 0.967 \\
\hline & No & $46(68.7)$ & $9(69.2)$ & \\
\hline \multirow[t]{2}{*}{ Weight loss" } & Yes & $30(44.8)$ & $6(46.2)$ & 0.927 \\
\hline & No & $37(55.2)$ & $7(53.8)$ & \\
\hline $\mathrm{BMl}^{*}\left(\mathrm{~kg} / \mathrm{m}^{2}\right)$ & & $27 \pm 4.5$ & $28 \pm 3.2$ & 0.480 \\
\hline LVEF* $^{*}$ & & $61 \pm 9$ & $63 \pm 9$ & 0.393 \\
\hline \multirow[t]{2}{*}{ Pulmonary function test* } & $\mathrm{FEV}_{1}$ & $97 \pm 17$ & $91 \pm 22$ & 0.318 \\
\hline & FVC & $97 \pm 14$ & $88 \pm 21$ & 0.1 \\
\hline \multirow[t]{3}{*}{ Preoperative laboratory results* } & Hematocrit & $35.7 \pm 5.5$ & $37.6 \pm 4.7$ & 0.249 \\
\hline & Albumin & $3.9 \pm 0.5$ & $3.9 \pm 0.5$ & 0.970 \\
\hline & Creatinine & $0.94 \pm 0.4$ & $0.76 \pm 0.2$ & 0.750 \\
\hline \multicolumn{5}{|c|}{$\begin{array}{l}\text { ASA: American Society of Anesthesiologists; HT: hyper } \\
\text { CAD: Coronary artery disease; BMI: Body mass index; LVE } \\
\text { SD: Standard deviation. } \\
\text { Datas are presented as *: mean } \pm \text { standard deviation. } \\
\text { \#: n (\%) }\end{array}$} \\
\hline
\end{tabular}

Therefore, appropriate anastomosis techniques and a detailed observation of anastomosis are required in order to prevent this complication (11).

Esophagojejunal anastomotic leakage prolongs the duration of hospitalization while increasing the risk of reoperation. It, at the same time, may lead to a fatal result. Sierzega et al. have reported that postoperative mortality rates increase, whereas survival rates decrease in patients with EJA leakage after total gastrectomy (5). Migita et al. have also reported that the mortality rate is $1.8 \%$ in 327 patients (11). The authors have stated that 3 out of 21 patients with EJA leakage died. Isozaki et al. have concluded that aggressive surgery for advanced stage gastric cancer increases the risk of anastomotic leakage as well (2). The results of our study, however, showed that $16.2 \%$ of the patients with EJA had anastomotic leakage, and this figure was higher than those reported in the literature. We believe that the reason why our EJA leakage rates were high is related to the fact that the majority of our patients had advanced stage tumors and received radical aggressive surgery. Although our leakage rate was high, our mortality rate was at an acceptable level at 1.2\%.

Deguchi et al. reported that pulmonary failure and the duration of operation are markers of EJA leakage in 1640 patients after 
Table 2. Intraoperative and pathological data of the patients

\begin{tabular}{|c|c|c|c|c|}
\hline Variable & & $\begin{array}{c}\text { Anastomosis leakage (-) } \\
n=67\end{array}$ & $\begin{array}{l}\text { Anastomosis leakage }(+) \\
n=13\end{array}$ & $\mathbf{p}$ \\
\hline \multirow[t]{4}{*}{ T stage ${ }^{\#}$} & $\mathrm{~T} 1$ & $6(9)$ & 0 & 0.148 \\
\hline & $\mathrm{T} 2$ & $5(.5)$ & 0 & \\
\hline & $\mathrm{T} 3$ & $25(37.3)$ & $9(69.2)$ & \\
\hline & $\mathrm{T} 4$ & $31(46.3)$ & $4(30.8)$ & \\
\hline \multirow[t]{4}{*}{ N stage s $^{\#}$} & No & $20(29.9)$ & $3(23.1)$ & 0.895 \\
\hline & N1 & $10(14.9)$ & $2(15.4)$ & \\
\hline & N2 & $18(26.9)$ & $3(23.1)$ & \\
\hline & N3 & $19(28.4)$ & $5(38.5)$ & \\
\hline No. of harvested lymph nodes* & & $26 \pm 11$ & $29 \pm 14$ & 0.603 \\
\hline No. of harvested metastatic lymph nodes* & & $5 \pm 8$ & $5 \pm 6$ & 0.587 \\
\hline \multirow[t]{2}{*}{ Combined organ resection ${ }^{\#}$} & Yes & $10(14.9)$ & $7(53.8)$ & 0.002 \\
\hline & No & $57(85.1)$ & $6(46.2)$ & \\
\hline \multirow[t]{2}{*}{ Duration of operation (min) ${ }^{\#}$} & $<300$ & $32(47.8)$ & $1(7.7)$ & 0.007 \\
\hline & $\geq 300$ & $35(52.2)$ & $12(92.3)$ & \\
\hline \multirow[t]{2}{*}{ Intraoperative blood transfusion ${ }^{\#}$} & Yes & $13(19.4)$ & $1(7.7)$ & 0.309 \\
\hline & No & 54 (80.6) & $12(92.3)$ & \\
\hline
\end{tabular}

Table 3. Multivariate analysis of intraoperative findings of the patients

\section{Variable}

Combined organ resection

Duration of operation (min)

\begin{tabular}{|c|c|}
\hline $\mathbf{p}$ & OR \\
\hline $0.008^{*}$ & 6.329 \\
\hline $0.032^{*}$ & 10.416 \\
\hline
\end{tabular}

$95 \% \mathrm{Cl}$

OR: Odds ratio; Cl: Confidence interval.

* Statistically significant at $p<0.05$.

total and proximal gastrectomy in their retrospective study (8). In our study, the duration of operation was markedly longer in the EJA leakage group than in the group with no leakage, and it was found to be statistically significant by both univariate and multivariate analyses. Various studies have also reported that prolonged duration of operation is related to morbidity after gastrectomy (16-18).

Many factors affect prolonged duration of operation. Complicated surgical procedures result in longer duration of operation and increase the risk of morbidity (19). Procedural duration is generally prolonged in advanced tumor cases, but it does not always lead to EJA leakage. Some studies have also reported that patients' risk of postoperative complications related to additional organ resections including splenectomy or pancreatectomy is higher (20,21). Deguchi et al. have found that the effects of additional organ resection on EJA leakage are statistically significant as revealed by univariate analysis (8). They, however, reported that the results of their multivariate analysis reveal that it does not have a determinant role on EJA leakage.

Migita et al. have reported that chronic renal failure, proximal gastrectomy, high levels of hemoglobin A1c, and problems seen in anastomoses during EJA construction are independent risk factors for EJA leakage, whereas combined additional organ resection is not related to EJA leakage in 327 patients (11).

The results of our study, however, showed that additional organ resection was statistically significant. Kiudelis et al. have ascertained that a 4-day average body temperature, leukocyte levels, and CRP levels during the early postoperative period are considerably related to anastomotic leakage as revealed by univariate analysis in 175 patients (22). The results of our study also demonstrated that the rates of EJA leakage and postoperative complications were significantly higher in patients with recurrent fever in the postoperative period $(p=0.01)$. When CRP values were investigated, it was seen that the CRP values on postoperative days 3 and 5 were higher in patients with postoperative complications including EJA leakage than in those without complications, and the difference between the two groups was statistically significant $(p=0.01)$. When the patients were assessed with regard to NLR, it was observed that NLR on postoperative day 5 was significantly higher in the EJA leakage and other postoperative complication group $(p=0.022)$. All these mentioned factors are essentially a result of the inflammatory effect of EJA leakage and are not specific to EJA leakage. 


\begin{tabular}{|c|c|c|c|c|c|}
\hline Variable & PO & $\begin{array}{l}\text { No Complication } \\
(n=46)\end{array}$ & $\begin{array}{l}\text { Anastomosis } \\
\text { leakage } \\
n=13\end{array}$ & $\begin{array}{c}\text { Another } \\
\text { Complication } \\
n=21\end{array}$ & $p$ \\
\hline \multirow[t]{3}{*}{$\mathrm{CRP}^{*}(\mathrm{mg} / \mathrm{dL})$} & Day 1 & $6.8 \pm 2.4$ & $9.8 \pm 3.9$ & $9.9 \pm 8.8$ & 0.201 \\
\hline & Day 3 & $8.3 \pm 3.4$ & $21.1 \pm 9.2$ & $22.7 \pm 13.3$ & 0.01 \\
\hline & Day 5 & $8.8 \pm 4$ & $17.4 \pm 7.2$ & $10.7 \pm 5.3$ & 0.01 \\
\hline \multirow[t]{3}{*}{$\mathrm{WBC}^{*}\left(10^{3} / \mu \mathrm{L}\right)$} & Day 1 & $13.59 \pm 4.91$ & $15.88 \pm 2.49$ & $13.62 \pm 3.72$ & 0.226 \\
\hline & Day 3 & $8.8 \pm 3.11$ & $12.02 \pm 3.79$ & $9.87 \pm 5.93$ & 0.077 \\
\hline & Day 5 & $8.44 \pm 2.94$ & $9.37 \pm 4.84$ & $8.7 \pm 3.8$ & 0.800 \\
\hline \multirow[t]{3}{*}{ Neutrophil-to-lymphocyte ratio* } & Day 1 & $16.6 \pm 13.8$ & $26.2 \pm 19.5$ & $22.1 \pm 20.3$ & 0.142 \\
\hline & Day 3 & $11.2 \pm 7.8$ & $16.7 \pm 13.5$ & $9.7 \pm 7.7$ & 0.146 \\
\hline & Day 5 & $6.2 \pm 2.9$ & $12.0 \pm 8.0$ & $9.7 \pm 7.4$ & 0.022 \\
\hline \multirow[t]{3}{*}{ Platelet-to-lymphocyte ratio* } & Day 1 & $379.9 \pm 315.7$ & $396.6 \pm 238.7$ & $492.5 \pm 363.5$ & 0.404 \\
\hline & Day 3 & $290.8 \pm 132.1$ & $303.4 \pm 221.5$ & $344.9 \pm 274.2$ & 0.682 \\
\hline & Day 5 & $308.6 \pm 109.1$ & $327.8 \pm 208.6$ & $503.8 \pm 726.8$ & 0.340 \\
\hline Fever $^{\#}$ & & $16(34.8)$ & $7(53.8)$ & $12(57.1)$ & 0.168 \\
\hline Recurrent fever ${ }^{\#}$ & & $2(4.3)$ & $6(46.2)$ & $4(19)$ & 0.001 \\
\hline \multicolumn{6}{|c|}{ 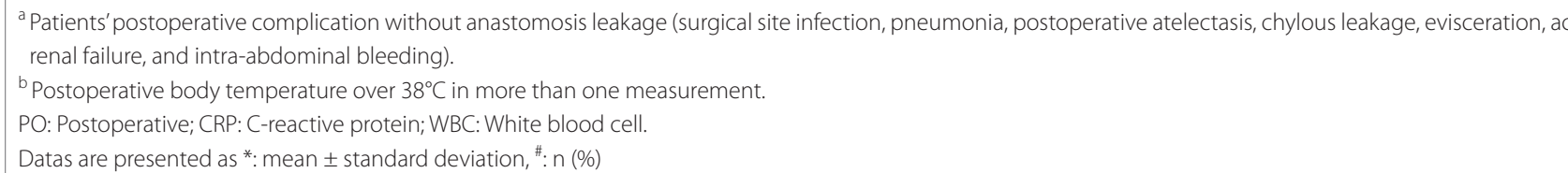 } \\
\hline
\end{tabular}

\section{Study Limitations}

The limitations of our study included the fact that it was retrospective, had a small patient population, and was conducted at a single center.

\section{CONCLUSION}

Surgeons should be careful about anastomotic leakage, which is a significant postoperative complication, especially in cases where the duration of operation is prolonged, and additional organ resection is required. Recurrent fever, high CRP levels, and NLR may serve as warnings for complications in postoperative follow-ups.

Ethics Committee Approval: Ethics committee approval was received for this study from the Ethics Committee of Kartal Koşuyolu Higher Specialty Training and Research Hospital (2017.3/2-36).

Informed Consent: Informed consent was not received due to the retrospective nature of the study.

Peer-review: Externally peer-reviewed.

Author Contributions: Concept - D.A.Ç., E.G.; Design - D.A.Ç., H.Ç., E.G.; Supervision - M.D., K.C.D.; Resource - M.D., K.C.D., O.U.; Materials - M.D., K.C.D., O.U.; Data Collection and/or Processing - D.A.Ç., H.Ç., U.A.; Analysis and/or Interpretation - D.A.Ç., E.G., U.A.; Literature Search - D.A.Ç., H.Ç., U.A.; Writing Manuscript - D.A.Ç.; Critical Reviews - M.D., K.C.D., O.U.
Conflict of Interest: The authors have no conflicts of interest to declare.

Financial Disclosure: The authors declared that this study has received no financial support.

\section{REFERENCES}

1. Ichikawa D, Kurioka H, Yamaguchi T, Koike H, Okamoto K, Otsuji E, et al. Postoperative complications following gastrectomy for gastric cancer during the last decade. Hepatogastroenterology 2004; 51:613-7.

2. Isozaki H, Okajima K, Ichinona T, Hara H, Fujii K, Nomura E. Risk factors of esophagojejunal anastomotic leakage after total gastrectomy for gastric cancer. Hepatogastroenterology 1997; 44: 1509-12.

3. Nomura S, Sasako M, Katai H, Sano T, Maruyama K. Decreasing complication rates with stapled esophagojejunostomy following a learning curve. Gastric Cancer 2000; 3: 97-101. [CrossRef]

4. Park DJ, Lee HJ, Kim HH, Yang HK, Lee KU, Choe KJ. Predictors of Operative morbidity and mortality in gastric cancer surgery. Br J Surg 2005; 92: 1099-102. [CrossRef]

5. Sierzega M, Kolodziejczyk P, Kulig J. Impact of anastomotic leakage on long-term survival after total gastrectomy for carcinoma of the stomach. Br J Surg 2010; 97: 1035-42. [CrossRef]

6. Hyodo M, Hosoya Y, Hirashima Y, Haruta H, Kurashina K, Saito S, et al. Minimum leakage rate (0.5\%) of stapled esophagojejunostomy with sacrifice of a small part of the jejunum after total gastrectomy in 390 consecutive patients. Dig Surg 2007; 24: 169-72. [CrossRef]

7. Lang H, Piso P, Stukenborg C, Raab R, Jähne J. Management and results of proximal anastomotic leaks in a series of 1,114 total gastrectomies for gastric carcinoma. Eur J Surg Oncol 2000; 26: 168-71.

[CrossRef] 
8. Deguchi Y, Fukagawa T, Morita S, Ohashi M, Saka M, Katai H. Identification of Risk Factors for Esophagojejunal Anastomotic Leakage after Gastric Surgery. World J Surg 2012; 36: 1617-22. [CrossRef]

9. Meyer L, Meyer F, Dralle H, Ernst M, Lippert H, Gastinger I. Insufficiency risk of esophagojejunal anastomosis after total abdominal gastrectomy for gastric carcinoma. Langenbecks Arch Surg 2005; 390: 510-6. [CrossRef]

10. Bruce J, Krukowski ZH, Al-Khairy G, Russell EM, Park KGM. Systematic review of the definition and measurement of anastomotic leak after gastrointestinal surgery. Br J Surg 2001; 88: 1157-68. [CrossRef]

11. Migita K, Takayama T, Matsumoto S, Wakatsuki K, Enomoto K, Tanaka T, et al. Risk factors for esophagojejunal anastomotic leakage after elective gastrectomy for gastric cancer. J Gastrointest Surg 2012; 16 : 1659-65. [CrossRef]

12. Crapo MD, Hankison JL, Irvin C, Mancityre NL, Voter KZ, Wise RA. American Thoracic Society: Standardization of spirometry: 1994 update. Am J Respir Crit Care Med 1995; 152: 1107-36. [CrossRef]

13. Dindo D, Demartines N, Clavien PA. Classification of surgical complications: a new proposal with evaluation in a cohort of 6336 patients and results of a survey. Ann Surg 2004; 240: 205-13. [CrossRef]

14. Edge SB, Compton CC. The American Joint Committee on Cancer: The $7^{\text {th }}$ edition of the AJCC cancer staging manual and the future of TNM. Ann Surg Oncol 2010; 17: 1471-4. [CrossRef]

15. Watanabe M, Miyata H, Gotoh M, Baba H, Kimura W, Tomita N, et al. Total gastrectomy risk model: data from 20,011 Japanese patients in a nationwide internet-based database. Ann Surg 2014; 260: 1034-9. [CrossRef]

\section{ORIJINAL ÇALIŞMA-ÖZET}

Turk J Surg 2019; 35 (1): 6-12
16. Kodera Y, Sasako M, Yamamoto S, Sano T, Nashimoto A, Kurita A. Identification of risk factors for the development of complications following extended and super-extended lymphadenectomies for gastric cancer. Br J Surg 2005; 92: 1103-9. [CrossRef]

17. Lo CH, Chen JH, Wu CW, Lo SS, Hsieh MC, Lui WY. Risk factors and management of intra-abdominal infection after extended radical gastrectomy. Am J Surg 2008; 196: 741-5. [CrossRef]

18. Yasuda K, Shiraishi N, Adachi Y, Inomata M, Sato K, Kitano S. Risk factors for complications following resection of large gastric cancer. Br J Surg 2001; 88: 873-7. [CrossRef]

19. Vural V, Saylam B, Comçalı B, Düzgün AP, Özer MV, Cosskun F. D1 versus D2 dissection in stomach carcinoma: Evaluation of postoperative mortality and complications. Turk J Surg 2013; 29: 1-6. [CrossRef]

20. Bonenkamp JJ, Songun I, Herman J, Sasako M, Welvaart K, Plukker JT, et al. Randomised comparison of morbidity after D1 and D2 dissection for gastric cancer in 996 Dutch patients. Lancet 1995; 345: 745-8. [CrossRef]

21. Bonenkamp JJ, Hermans J, Sasako M, Welvaart K, Songun I, Meyer S, et al. Extended lymph-node dissection for gastric cancer. N Engl J Med 1999; 340: 908-14. [CrossRef]

22. Kiudelis M, Bernotas J, Mickevičius A, Endzinas Ž, Maleckas A. Riskfactors of esophagojejunal anastomosis leakage after total gastrectomy. Lithuanian Surgery 2013; 12: 20-4.

\title{
Total gastrektomi sonrası özefagojejunal anastomoz kaçağında risk faktörleri
}

\author{
Durmuş Ali Çetin ${ }^{1}$, Ebubekir Gündeş ${ }^{2}$, Hüseyin Çiyiltepe ${ }^{3}$, Ulaş Aday ${ }^{4}$, Orhan Uzun ${ }^{5}$, Kamuran Cumhur Değer ${ }^{5}$, Mustafa Duman ${ }^{5}$ \\ 1 Şanlıurfa Eğitim ve Araştırma Hastanesi, Gastroenteroloji Cerrahi Kliniği, Şanlıurfa, Türkiye \\ ${ }^{2}$ Diyarbakır Gazi Yaşargil Eğitim ve Araştırma Hastanesi, Gastroentereloji Cerrahi Kliniği, Diyarbakır, Türkiye \\ ${ }^{3}$ Fatih Sultan Mehmet Eğitim ve Araştırma Hastanesi, Gastroentereloji Cerrahi Kliniği, İstanbul, Türkiye \\ ${ }^{4}$ Elazığ Eğitim ve Araştırma Hastanesi, Gastroenteroloji Cerrahi Kliniği, Elazığ, Türkiye \\ ${ }^{5}$ Kartal Koşuyolu Yüksek Ihtisas Eğitim ve Araştırma Hastanesi, Gastroenteroloji Cerrahi Kliniği, İstanbul Türkiye
}

\section{ÖZET}

Giriş ve Amaç: Mide kanseri cerrahisinde perioperatif yönetim ve cerrahi teknikteki gelişmelere rağmen, total veya proksimal gastrektomi sonrası yapılan rekonstruksiyonda özefagojejunal anastomoz (ÖJA) kaçağı halen önemli bir morbidite ve mortalite nedenidir. Bu çalışmada, ÖJA kaçağı açııından risk faktörlerinin belirlenmesi amaçlanmıştır.

Gereç ve Yöntem: Ocak 2013 ile Aralık 2016 tarihleri arasında total gastrektomi +D2 lenf nodu diseksiyonu ve ÖJA yapılan 80 mide kanserli hasta retrospektif olarak değerlendirildi. Klinik takipleri sırasında anastomoz kaçağı gelişmeyen hastalar grup 1'í, anastomoz kaçağı gelişenler ise grup 2'yi oluşturdu.

Bulgular: Çalışmaya dahil edilen 80 hastanın 58 (72.5\%)'i erkek, 22 (27.5\%)'si kadın olup yaş ortalaması $61.2 \pm 11.2$ idi. Gruplar arasında demografik özellikler açısından farklılık saptanmadı. Postoperatif tekrarlayıcı ateş ( $p=0.001)$, postoperatif 3. ve 5. gün C-reaktif protein (CRP) değerleri $(p=0.01)$ ve postoperatif 5. gün nötrofil/lenfosit oranı (NLO) $(p=0.022)$ ÖJA kaçağı ve diğer postoperatif komplikasyonlar açısından istatistiksel olarak anlamlı saptandı. Operasyon süresi $(p=0.032)$ ve kombine organ rezeksiyonu $(p=0.008)$ ÖJA kaçak açısından risk faktörleri olarak belirlendi.

Sonuç: Cerrahlar özellikle operasyon süresinin uzadığı ve ek organ rezeksiyonunun yapıldığı durumlarda, ameliyat sonrası önemli bir komplikasyon olan ÖJA kaçağı açısından dikkatli olmalıdırlar. Postoperatif dönemdeki takiplerde tekrarlayan ateş, yüksek CRP değeri ve NLO komplikasyonlar açısından uyarıcı olabilir.

Anahtar Kelimeler: Anastomoz kaçağı, gastrektomi, risk faktörleri

Doi: $10.5578 /$ turkjsurg. 4117 